\title{
A Food Safety Crisis in China: Issues and Opportunities
}

\author{
Gregory Veeck* and Ann Veeck \\ Department of Geography and Marketing, Western Michigan University, USA
}

Submission: May 22, 2018; Published: June 22, 2018

"Corresponding author: Gregory Veeck, Department of Geography and Marketing, Western Michigan University, USA, Email: veeckg@wmich.edu

Keywords: Food safety; Public security; Heavy metals; Antibiotics or Farm chemicals

\section{The Problem}

A survey conducted in sixteen major Chinese cities in 2012 ranked "food safety" as the \# 1 concern of a significant majority of respondents (81.8\%). Food safety was a more frequently cited concern than problems with public security (49\%), medical care (36.4\%), transportation (34.4\%) and the environment (20.1\%). Similar research published in 2015 evidenced similar sentiments [1]. Anxiety related to food safety is more than justified. Every day, consumers are confronted with alarming stories in the media related to tainted food, counterfeit food, or crops polluted with heavy metals, antibiotics or farm chemicals. Poisonings in restaurants of all types due to adulterated foods or poor sanitation are common-place. Many recognize a new "Chinese Food Crisis," not based on food shortages as in the 1960s and 1970s, but due to poor food safety standards [2,3]. In a 2013 survey of 337 households conducted in Nanjing, a majority of respondents reported feeling powerless to avoid common sources of risk associated with food. On a seven-point scale where 1 equals unavoidable risk and 7 equals avoidable risk, seven of nine types of food safety concerns were ranked as "always unavoidable", "mostly unavoidable" or "usually unavoidable" (Table 1). Unlike in surveys of Western consumers, concern about "Counterfeit Foods " ("fake" foods) and foods contaminated by chemicals or bacteria outweigh worries regarding GM foods, meat infected by animal diseases such as BSE ("mad cow"), or even food insecurity (insufficient food) [1]. Problems throughout China's food system have left consumers feeling powerless and angry.

Table 1: Responses to a survey of 337 urban households in Nanjing, China where the primary food preparer in the household was asked to rank problems related to food with respect to their ability to avoid the problem when preparing meals for their family.

\begin{tabular}{|c|c|c|c|}
\hline $\begin{array}{c}\text { List of Food-Related Safety Concerns and Respondent's Concern Regarding } \\
\text { their Ability to Avoid them Where 1= Cannot Avoid to 7= Highly Avoidable }\end{array}$ & $\begin{array}{c}\text { Rank Where 1 = } \\
\text { Greatest Concern }\end{array}$ & $\begin{array}{c}\text { Mean Score on } \\
\text { 7 Point Scale }\end{array}$ & $\begin{array}{c}\text { Std. Deviation } \\
\text { of Mean Score }\end{array}$ \\
\hline Counterfeit foods & 1 & 3.37 & 1.70 \\
\hline Chemical contamination & 2 & 3.37 & 1.61 \\
\hline Toxic food from pollution & 3 & 3.46 & 1.87 \\
\hline New technologies & 4 & 3.64 & 1.65 \\
\hline Bacterial contamination & 5 & 3.71 & 1.62 \\
\hline Food hygiene problems & 6 & 3.89 & 1.79 \\
\hline Animal diseases & 7 & 3.90 & 1.73 \\
\hline Non-nutritious foods & 8 & 4.06 & 1.61 \\
\hline Lack of food & 9 & 4.83 & 1.69 \\
\hline
\end{tabular}

Some of the most bizarre scams related to "fake" foodsincidents most reported by the international press -- are usually perpetrated by unscrupulous small to medium firms looking for a quick buck. In reality these cases, however gross, actually impact a relatively limited number of consumers. Examples include: rat meat passed off as lamb in Beijing restaurants, re-packaged "past date" noodles and other dry goods, and fake "honey" or "juice" made from syrup, dye and water. Our personal vote for "most outrageous" was the fake hairy crab scandal where the hair scraped from consumed crabs gathered from restaurant 
trash was glued to low-cost crabs of another species similar in appearance that were then painted to look like genuine freshwater hairy crabs, a famous Yangtze River Delta dish in great demand for wedding banquets and by epicures. More pervasive and corrosive to national trust than these "headliners" is the extensive large-scale manufacture of substandard or adulterated juice, milk, flour, noodles, pork, and other daily staples sold by unsuspecting retailers, often in counterfeit packaging that mimic popular and trusted brands. Such illegal and immoral acts have left consumers with a high level of mistrust for both food producers, and all those merchants and manufacturers associated with the urban food supply chain.

If the steady drip of scandals caused by deliberate adulteration or poor sanitation was not enough, China's consumers also face systemic pollution of staples such as rice, corn and wheat due to polluted soil and/or ground water. Tests on rice grown in Hunan Province, China's most important rice-growing province, found cadmium, a widely recognized carcinogen, at toxic levels throughout the province. A study conducted in Guangzhou, China's $3^{\text {rd }}$ largest city at 13 million persons, found that over $50 \%$ of the rice for sale in local markets was polluted with dangerous levels of cadmium-pushing sales of rice imported from Vietnam and Thailand to record levels. Of course, many other farm products such as vegetables, fruits, fish, crayfish, shrimp and even tea are similarly impacted.

Even well-intentioned multinational firms operating in China or exporting from China find themselves ensnared in scandals arising from the inadvertent distribution of substandard products linked to the use of locally-sourced polluted meats and vegetables. In 2014, Walmart tripled expenditures on food product testing after a popular pre-cooked product known as "Five Spice Donkey Meat" was found to contain fox meat-presumably less tasty if slightly more exotic. Other multinationals such as Nestles (melamine in the milk), and McDonald's, Papa Johns, and Burger King (expired beef and chicken repackaged and sold to these firms with new dates) have had to deal with months-long public relations nightmares and lowered revenues because of tainted food. Experts believe the controversial 2013 acquisition of Smithfield Foods by the Chinese firm, Shuanghui, was pursued in part to gain access to state-of-the-art processing and storage technologies, but also to burnish the reputation for quality of the local brand. Before the merger, Shuanghui was implicated in numerous quality and sanitation scandals.

Looking past the domestic market, China's exports significant amounts of food, increasing from $\$ 2.98$ billion worldwide in 1980 to more than $\$ 60$ billion in 2017. The United States is a major importer of food from China, including fish, shrimp, canned chicken and pork, apple and other fruit juices, honey, condiments and spices such as red pepper, onion powder, fresh and dried garlic and even essential flavoring oils such as mint, spearmint, and cinnamon. The food quality crisis in China is, then, both a national and international problem.

\section{The Response}

There is no shortage of new laws and regulations intended to stem the crises and establish a culture of prevention. China's leadership views food safety as a very significant problem and has invested heavily in recent years to promote better outcomes ranging from expanded testing, regulation, and prosecution, to the promotion of HACCP production systems. In 2009, the comprehensive national food safety law was completely revised incorporating greater penalties, higher standards, and clearer guidelines. In 2010, the newly-created National Center for Food Safety Risk Assessment was assigned oversight of over 1,200 testing centers while coordinating food-related safety and testing programs originating from dozens of government agencies. Further national food safety guidelines and contaminant thresholds were passed in the past decade as well. High-profile cases, including prosecution of China's three largest milk producing firms associated with the melamine scandal of 2008, were seen as the cutting edge of what many hoped would be a zero tolerance position for unsafe foods by the government. The government also introduced "safe food" labeling to identify foods that are routinely tested for purity and quality, but this campaign has been undermined by the subsequent counterfeiting of the widely-recognized "S" holographic stickers.

Certainly, a critical aspect of the problem is related to the sheer scale of the nation's food system. Shao estimated that in 2011, there were more than 400,000 food processing firms operating in China and a staggering 32 million firms selling food to domestic consumers or exporting food products to international markets. How can the state monitor this many operations? How can a culture be created in which a HACCP-type self-monitoring is embraced by more than 30 MILLION businesses, large and small, often operating with razor-thin profit margins?

There are regularly occurring tainted food crises related to bacterial pollution and chemical residues in the food systems of all nations, including North America, the EU and other technically-advanced farming regions. Still, China's problems appear more systemic and somehow harder to address and prosecute than most. There are so many people involved at so many levels. Farmers cannot control the quality of irrigation water used on their land-and often do not introduce the sources of pollution found in their crops. The absence of government payments to compensate for confiscated grain discourages participation in assessment programs and, untested, these grains move upward in the supply chain to markets, processors, bakers, and ultimately, consumers. This weak political-legal framework is part of the problem, and improvement in this area must be part of the solution.

\section{The Opportunities}

China's food quality issues represent a number of opportunities for the sales and licensing of products and services throughout all segments of the food supply chain. Because of 
greater government involvement, and especially the popularity of the internet, incidents related to polluted food and counterfeit foods are now routinely reported by mainstream media and increasingly by consumer protection NGOs--underscoring the importance of a free press and an uncensored internet. Greater transparency has raises awareness and encourages the government to punish perpetrators and compensate victimsboth consumers and producers. These Chinese media reports can serve as an accessible resource to alert firms to important business opportunities where the sale of "jansan" (janitorial and sanitation) products and technologies from North America, Japan, and the EU nations can improve safe and sanitary production environments and processes.

The demand for "certified organic" products in China represents a good example of how the costs of improved food safety can be incorporated into higher consumer prices. Despite retail prices that are double or even triple the price of regular vegetables, many urban consumers are more than willing to pay higher prices for organic products to mitigate risk to their families. We believe the same conditions exist for many other staples and processed foods. Organic and hydroponic vegetable producers are now a common feature in almost every city in China. Some of these producers use sophisticated technologies imported or adopted from providers in Japan, Israel, or the US/ Canada, BUT the vast majority of these farmers (often immigrants with 1-year leases on the land) do not. Most producers within or adjacent to cities simply produce product in traditional plasticcoated greenhouses ranging in size from 0.2 to 0.7 ha with multiple crops per year-setting the stage for herbicide pollution issues specifically. There is little certification of these products with sales going either directly to consumers via wet markets, or sales to wholesale markets that do not always have the capacity for testing to assure the vegetables and fruits that are procured from hundreds or thousands of small-scale farmers are indeed "organic" or safe.
The current state of affairs represents a significant challenge to the Chinese government at all levels, BUT also a major opportunity for internationally-sourced equipment and many other food safety products as well. Foreign companies and entrepreneurs offering upgraded technical services and product lines related to sanitation, processing, product testing and packaging are all needed. From food companies to restaurants, there is a need for affordable sanitation products, perhaps produced in-country through licensing agreements. We believe that consumers are willing to pay for greater security, if the safety of the products and production technologies can be documented. The need for trusted products exists throughout the food supply chain. To cite just one example, seven million disposable foam food containers were seized in Jiangxi Province when found to contain toxic chemicals that were released when the containers were heated or even simply warmed by food [4]. Demand for higher-quality food service disposables and single use food service items-especially "green" versions of these productsare in great demand and represent significant opportunities for international firms that are respected and offer the proper services. Until the technologies and supply chains for organic and safe foods are upgraded to meet EU/Japan/Korea/Australia/ NZ and North American standards, consumers will never be completely secure in the safety of their food purchases. Yes, the Chinese government must do more, but the role of western technologies and products must not be overlooked.

\section{References}

1. Veeck G, Veeck A, Zhao S (2015) Perceptions of Food Safety by Urban Consumers in Nanjing, China. Professional Geographer 67(3): 490-501.

2. Huang Y (2012) China's Worsening Food Safety Crisis. The Atlantic.

3. Huehnergarth N (2014) China's Food Safety Issues Worse Than You Thought. Food Safety News.

4. Peter F (2011) Top 10 China Food Scandals. The Telegraph.

\section{Your next submission with Juniper Publishers will reach you the below assets}

- Quality Editorial service

- Swift Peer Review

- Reprints availability

- E-prints Service

- Manuscript Podcast for convenient understanding

- Global attainment for your research

- Manuscript accessibility in different formats

( Pdf, E-pub, Full Text, Audio)

- Unceasing customer service

Track the below URL for one-step submission https://juniperpublishers.com/online-submission.php 